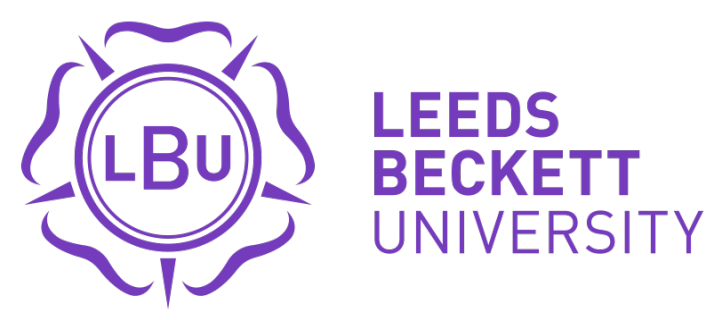

Citation:

Curtis, L and Samy, M (2014) Investigating whether UK business schools need to be more business-like in order to survive in today's dynamic environment. International Journal of Educational Management, 28 (6). 728 - 750. ISSN 0951-354X DOI: https://doi.org/10.1108/IJEM-08-2013-0133

Link to Leeds Beckett Repository record:

https://eprints.leedsbeckett.ac.uk/id/eprint/1766/

Document Version:

Article (Accepted Version)

The aim of the Leeds Beckett Repository is to provide open access to our research, as required by funder policies and permitted by publishers and copyright law.

The Leeds Beckett repository holds a wide range of publications, each of which has been checked for copyright and the relevant embargo period has been applied by the Research Services team.

We operate on a standard take-down policy. If you are the author or publisher of an output and you would like it removed from the repository, please contact us and we will investigate on a case-by-case basis.

Each thesis in the repository has been cleared where necessary by the author for third party copyright. If you would like a thesis to be removed from the repository or believe there is an issue with copyright, please contact us on openaccess@leedsbeckett.ac.uk and we will investigate on a case-by-case basis. 


\title{
Investigating whether UK business schools need to be more business-like in order to survive in today's dynamic environment
}

\begin{abstract}
Purpose - The purpose of this paper is to explore whether UK business schools need to change their strategy, to adopt a more business-like approach, without compromising their role as providers of 'quality education.' Businesslike activities, as explained by Dart (2004: 294) are generally understood to be those characterised by some blend of profit motivation, the use of managerial and organisation design tools developed in for-profit business settings, and broadly framed business thinking to structure and organise activity.
\end{abstract}

Design/methodologylapproach - Adopting a mixed methods research design, this study involved the review of quantitative data from questionnaires sent to senior managers within UK business schools, followed by the casestudy analysis of five business schools.

Findings - Contemporary evidence suggests business schools have reacted to the current dynamic environment by adapting a more business-like approach, scanning the horizon and identifying new markets and opportunities for growth. However, some business schools remain ardently against a more business-like approach, considering it to work against academic clarity and research excellence, expected of universities.

Originality/value - This paper illustrates the current challenges influencing strategy within five diverse UK business schools. Therefore, the original contribution of the paper lies in the authors' empirical investigations into the current thinking of business school leaders, in light of the changing HE policies and reduced funding arrangements. In doing this it reflects on future strategic choices in order to ascertain if adopting an approach more in line with private business, with a sharper focus on efficiency and operating profit is inevitable or perhaps even advisable, in order to survive and promote growth in today's dynamic environment. It calls for business schools to proactively take responsibility for more carefully balancing the incomes, with more of a realisation that members of the school will need to generate these resources by demonstrating continuous innovation.

Keywords - Business-like, Strategy, Competitive environment, Strategic formulation, Strategic change, Marketing, Business Schools

Paper type - Research paper 


\section{INTRODUCTION}

In an increasingly cash-starved HE sector, UK business schools, based within UK universities have historically proven to be important income generators (Ivory et al, 2005). However, as Khalifa (2009:72) states “... higher education is facing new realities as universities in many countries are experiencing financial pressures and budget constraints." Even prior to funding cuts, D'Alessio and Avolio (2009) confirms it was an on-going challenge for most business school deans to cover operational costs and support research efforts as the traditional model of accomplishing this task solely from student tuition is insufficient to meet today's international market demands. A position that has led some critics (Harrington and Kearney, 2011) to suggest the business landscape is undergoing significant change as new educational technologies; a new generation of students, innovative competitors and the decline of public funding create what Kirp (2003:14) has labelled "academic capitalism."

Some researchers argue universities across the board need to be more business-like in their focus (Ball, 2012), as proponents of the importance of strategic goals (Martin, 2013) effective financial and change management via their teaching programmes, there is plausibly a greater expectation for business schools to lead the way. Certainly, Thomas and Wilson (2011:44) support this by suggesting due to the rapid growth of business schools internationally, they are becoming more like a "business in their own right." Lorange (2013) also suggests business schools are increasingly needing to be responsive to changing market requirements, while recognising the importance of being performance-led; a position more in line with businesses arguably. However, given the public debate about the value proposition of business schools (Cornuel, 2007) there are potentially key questions that still need to be investigated in order to 
understand the impact on future strategic direction. These questions focus on quantifying what the strategic choices are for today's business schools (Wilson and Thomas, 2012, Lorange, 2012), whilst seeking an understanding of the past and a predictive view of future strategic priorities; including an evaluation of the constraints and opportunities, as well as the direction of strategic change required to sustain survival for many, and encourage growth for the fortunate few. Furthermore, this can perhaps only really be understood by empirically analysing the strategic approach within different types of existing business schools, providing insights based on current practice, in order to stimulate debate and discussion relating to their future strategic direction and evolving nature.

The purpose of this paper is therefore to determine whether UK business schools need to review their strategy, to adopt a more business-like approach without compromising their role as providers of 'quality education.' A key element is an investigation into the strategic choices available to UK business schools, to facilitate more effective partnership with businesses, communities, other business schools and the wider society (Rayment and Smith, 2013). To further examine if there is a relationship between those UK business schools adopting a business-like approach through effective change management (Friga et al, 2003, Thomas and Thomas, 2011) and marketing strategies (Ivy, 2008, Moogan, 2011) and with financial and reputational success (Siebert and Martin, 2013).

\section{LITERATURE REVIEW}

Business schools as Hay, (2008:371) argues are: "One of the great educational success stories of the last century, perhaps the great story", due in part to the fact that as the business world has internationalised so, too, has business education (Muff, 
2013, Bevelander, 2012). This alludes to a position as Cornuel (2005) states of legitimacy for business schools. This may be due as Thomas and Thomas (2011) suggest, to the fact in the modern university the business school is currently valued much more for its managerial expertise, cash-generation abilities and financial strength than its intellectual capabilities and scholarship. Bok, (2003 and Angus 2010 as cited in Thomas and Thomas, 2011:526) berate senior university personnel for abandoning the fundamental ideals and visions of universities as: ..."thinking institutions" and "generators of new knowledge." From their perspective senior managers have "...instead championed business schools and commercial relevance as criteria for university success and growth" reducing the focus to "...marketisation, market values and financial stability."

Given the declining public funding provision, it may be feasible that adopting a strategic approach more in line with private business, with a sharper focus on efficiency and operating profit is inevitable, or perhaps even advisable. There is certainly an increasing financial pressure on business schools as Prince, (2007) outlines, due to an increase in competition for students (at home and internationally), and tighter, more targeted Government funding of students and research. These essentially competing strategic issues are highlighted by Starkey and Tempest (2008: 379) who argue stakeholders in business schools have differing views of what business schools should be doing; “...business tends to see business schools as a provider of services, while academics see themselves as producing knowledge of business rather than for business." As a result, commentators (Pfeffer and Fong, 2002, Thomas and Cornuel, 2011) suggest business schools are reaching a strategic crossroads in their development, uncertain about which route to take in the long-term. As Starkey et al $(2004: 1,527)$ highlight, part of the issue is because "...the business 
school stands at the fault line where the future of the university and the future of society interact." Consequently, Thomas and Cornuel (2011/2012) argue, issues such as the influence of internationalisation and innovation, the value and impact of research, and the importance of clear perspectives about corporate social responsibility and leadership are at the forefront of this continuing re-evaluation of the business school. These essentially competing demands help to inform the debate as to whether business schools could, or should be, more business-like; or if they can achieve more than one of these objectives.

\section{Challenges Facing Business Schools in the UK: Competitive Environment}

As D'Alessio and Avolio (2010) suggest the international arena generated by the global economy is obliging Deans (or their equivalents) to be creative, especially by expanding their school's operations into new markets to make their growth sustainable. With this in mind it may be considered that some business schools are already adopting a 'business-like' approach, assessing the competitive environment and realigning their strategic direction. Certainly, this favourable international environment as Hawawini (2005) highlights, provides a great opportunity for business schools located in high-growth economies, but it also raises a number of challenging issues, particularly for those located in mature countries, such as the UK.

The consequences of 'under-funding', balanced against pressure from governments and regulatory bodies, (such as the Quality Assurance Agency (QAA), with its focus on teaching quality and the Research Excellence Framework (REF) with its focus on research quality) requires business schools to balance quality education against a criteria of cost efficiency and organisational effectiveness. While student demand patterns and increased competition to attract more students (at home and 
internationally) will, Lorange (2013) suggests require schools to pay increasing attention to flexible learning. Social factors (such as the rise in retirement age) should increase demand for innovative forms of life-long learning, although this need could also be fulfilled by the emergence of 'corporate schools', consultants and in-house non specialist training (Muff, 2012).

Syvertsen (2008) suggests business schools are in a position where the ability to innovate is regarded as a source of developing competitive advantage. Furthermore, March and Leonard-Barton (1992) suggest, a business school can centre its attention on sets of techniques to cultivate valuable and commercially viable products and services, often referred to as the exploitation of knowledge for profit, in the same way that a business would. Although critics of a more business-like strategic approach such as Starkey and Tempest (2008:379) argue the tendency of business schools has always been to move "... along a vector which tends to emphasise business - and one model of business - at the expense of school" and what is needed is to better understand the impact of business and how management can become more effective.

\section{Strategic Choices: Business School Strategy: An Analysis of Past and Present}

Friga et al (2003) describes how the general value chain has remained relatively unchanged over the past 50 years, business schools have some unique characteristics that have shaped their strategies over time. This includes the make-up of their faculty, as Friga et al (2003) highlights, which in the 1950's included predominantly business professionals. While up until 1999, those who have attained a PhD populated it, and from 2000 onwards it is a mix of academics and professionals. Despite the mixed make-up of faculty however, the senior management teams in today's business schools are often led by business school deans or their equivalent 
Head of school, with an average tenure as Schlegelmilch and Thomas (2011) outline, of five years, so their concerns tend to be primarily short term and centre predominantly on increasing student numbers.

An article in The Economist ('Light on their feet', 2006) likened deans to sports' coaches, hired to improve performance, fired at will, but with one eye always on building their careers. As such it can be argued that some critics already envisage business schools are moving closer towards the 'profit-maximising' strategic approach than ever before, due in part to increased international competition for quick results in terms of the number and calibre of students. Current strategic approaches are moving away from what Whittington (2006:2) describes as the 'Systemic approaches' to the more business-like 'Classical', which is primarily focussed on remaining profitable. Indeed, it is suggested by Friga et al (2003) traditional business school strategy amounted to controlling capacity, in the belief that exclusivity aids in developing reputation, whilst new economic models could lead to a preference for high-volume, low margin versus low volume-high margin strategies. This may be challenging however with the implementation of the Government's white paper on the future of higher education in England, ('Students at the Heart of the System' 2011) which pledges to do "...more than ever to put students in the driving seat" especially as universities will be as Willets and Cable (2011:2) outline, “...under competitive pressure to provide better quality and lower cost."

\section{The Future: Strategic Choices}

Given the current competitive environment, Muff (2012) suggests modern business schools need to listen more closely to business leaders when developing their 
curriculum in order to increase relevance and business-like practices. While Starkey and Tiratsoo (2007) suggest for many in business schools the automatic response to these changes in the competitive environment has been to concentrate on the bottom line, such as increasing fees. In fact a study by the Association to Advance Collegiate Schools of Business highlights a $33 \%$ rise in MBA tuition and fees at AACSBaccredited business schools in North America and Asia-Pacific since 2007-08, with more modest increases reported in Europe and Latin America (Lavelle, 2013).

\section{The Influence of Internationalisation}

As Onzono and Carmona (2007) confirm the process of internationalisation that influences the strategy and operations of firms also exerts a considerable impact on business schools. Wilson (2007) explains this by stating the Bologna Accord has redefined the landscape in Europe, creating a fertile soil for the development of new schools and new programmes. D'Alessio and Avolio (2009) suggests top-tier business schools, especially in the U.S, have been able to diversify revenue generation in creative ways, such as selling journals, case studies, books, magazines, newsletters and other publications. Although, Pfeffer and Fong (2004, p.15) suggest business schools have responded to increasingly competitive dynamics by presenting themselves as "players" competing in this education industry. Strategically, this has resulted as Pfeffer and Fong (2004) outline with business education in the U.S increasingly seen as an industry ripe for consolidation, with the introduction of new technology such as e-learning and profit-making ventures such as UNext, the University of Pheonix, and similar organisations (Rukstad and Collins, 2001, as cited in Pfeffer and Fong, 2004:16). While, Harvard Business School now publishes an annual report that reads like a corporate annual report, including financial information showing whether or not the school is operating with a surplus and detailing the growth 
in the various sources of funding for the school, including executive education and Harvard's various publishing activities, (Pfeffer and Fong, 2004). This suggests to some extent that business schools in the U.S, in particular, are already responding to market pressure by becoming 'more business-like' but this approach, it could be stated, takes the focus away from quality education, societal engagement and improvement.

This debate is also attested by Rangnekar, (2011, cited in Fontanella-Khan, 2011: 1), Dean of the Indian School of Business when he describes the fact he "...faces a dilemma": be a top-ranked global school that competes with western institutions or specialise as an emerging-market centre that focuses on finding solutions for developing economies. Shahaida et al (2009:61) highlights education today is a trillion dollar industry in India, although most business schools claim a dual mission: to educate practitioners and to create knowledge through research, while embracing the scientific model of physicists and economists, rather than the professional model of doctors and lawyers. However, as Shahaida et al (2009) reflects because business schools are at arm's length from actual practice, they often fail to reflect the way business works in real life.

President of the Pennsylvania State University Graham Spanier (Baker, 2010:1), warns the UK sector; stating a decline in Government support for universities is "inevitable" and higher education must embrace entrepreneurialism to survive, However, Spanier also highlighted there is a risk of undermining "long-term traditions and values" if universities become too business-focused (Baker, 2010:1). It is clear though in the UK that due to the combined issues of reduced funding and increased competition from other International business schools and the private higher education sector that continuous change is inevitable, just as it has been for more than 30 years 
since formal rankings were introduced, which highlighted the concept of competing for student numbers, faculty and results.

Prince (2004) argues commercial activity, and the income it generates, are of increasing importance to all higher education institutions, in particular for new university business schools in the UK; as the funding climate has produced a scenario in which commercial activity is likely to be an increasing priority as business schools attempt to remain solvent. As Ozono (2007:25) suggests business schools will also need to 'field the demand from the real world to develop research which can actually address the real problems of business, 'adopting what could be described as a more traditional business-like approach, based on directly meeting the needs of customers. Bierach (2010:1) highlights, as business schools face unprecedented challenges not only are the tools and techniques used to reach prospective students changing, but also the marketing strategies employed.

\section{$\underline{\text { Impact upon marketing strategies }}$}

Moogan (2011) outlines that the introduction of the 'Higher Education Act 2004', with subsequent legislation that led to the introduction of student fees, has created a consumer environment, leaving the higher education (HE) sector in a difficult position of trying to balance academic integrity with the requirements of students. In addition as Moogan (2011) reiterates increased competition between institutions and the removal of government caps on student numbers exceeding stated targets impacts on the marketplace. 
As a direct result, increasingly, as Balmer (2010) suggests, deans of business schools, in both Europe and North America, are according greater importance to their corporate brands. As Anderson (2006, cited in Balmer et al, 2010:77) highlights, from a strategic perspective, the acquisition of a favoured corporate brand heritage is often equated with the ability to command higher fees for courses - particularly at Masters level. In order to build and sustain brand awareness, more emphasis, it may be argued is being focused on integrated marketing strategies to create greater brand equity, increase reputational appeal and subsequently student numbers. Therefore this study examines the extent of the dynamic environment, influenced by current funding structure and internationalisation and its impact on the future strategic direction for UK business schools. .

Based on the extensive review of current literature, the authors propose the following model (Figure 1.1) to identify and address the challenges and possible opportunities currently facing UK business schools. From the literature review, themes were developed to form the basis of the conceptual framework for this research. Adopting an interpretivism philosophical paradigm, the research examines the thematic analysis based on the perceptions of respondents. 
Figure 1.1: Strategic Issues for UK Business Schools
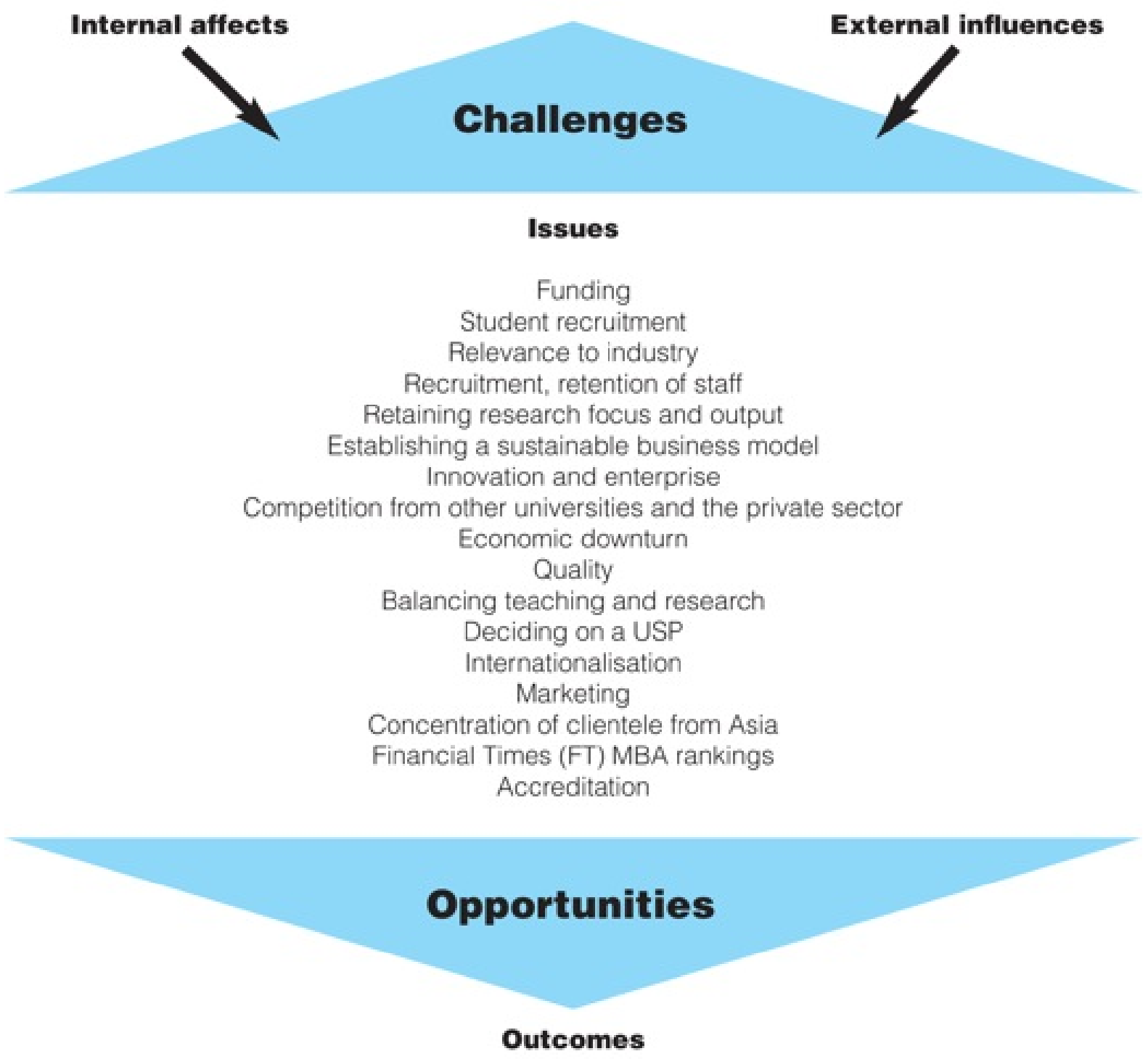

Income generation initiates creative enterprise Increase in the number and delivery methods for courses

Mutual benefit of partnerships with local businesses More diverse role for staff

Co-ordinated research with industry

Emerging new business models which will prove more sustainable Competitive environment prevents complacency and drives innovation Economic climate necessitates constant re-evaluation and consistent quality Teaching and research given equal weighting More clearly defined USP in order to integrate Internationalisation strategically Marketing provides a chance to re-establish identity and imbed USP

Rankings and accreditation support quality and sustainability 


\section{METHODOLOGY}

\section{Data Collection}

Quantitative and qualitative data were collected from deans and senior managers within UK business schools, using an electronic questionnaire and case-study analysis of five diverse business schools.

\section{Questionnaires}

The survey questionnaires were refined through an iterative process of interviews, reviews and revisions with senior managers from two East of England business schools. The questionnaire was then sent via e-mail to the deans/heads and directors of all the Business Schools (BS) in the UK based on the November 2012 Association of Business Schools membership list - 109 schools. Although a comprehensive listing of UK business school senior managers is not published; a database was originated to include between 1-3 senior managers per school utilising information from each website. All questionnaires were sent via e-mail and a request was made for them to be returned in the same manner. A follow-up to non-respondents was made via e-mail.

The structure of the questionnaire included several series of questions/statements with scaled responses and several open-ended questions in order to contextualise the overall experiences of senior managers in the current dynamic environment. The following factors were analysed in order to assess whether business schools need to be more business-like: strategic issues facing business schools, past, present and future; market orientation; biggest challenges over the last three years, versus the next three years; importance of building and maintaining relationships with: other business schools, local businesses, community groups, Government and society as a whole; 
nature and location of competition; evaluation and development of strategy; strategic change, including barriers and marketing, in terms of resource and prioritisation. Descriptive statistics and diagrams were used as part of the data analysis.

\section{$\underline{\text { Case Studies }}$}

Semi-structured interviews were arranged with senior managers from five UK business schools, categorised under the following headings in order to secure anonymity and maintain confidentiality (as illustrated in Figure 1.2 below, Case Study Analysis).

\section{Case Study Analysis}

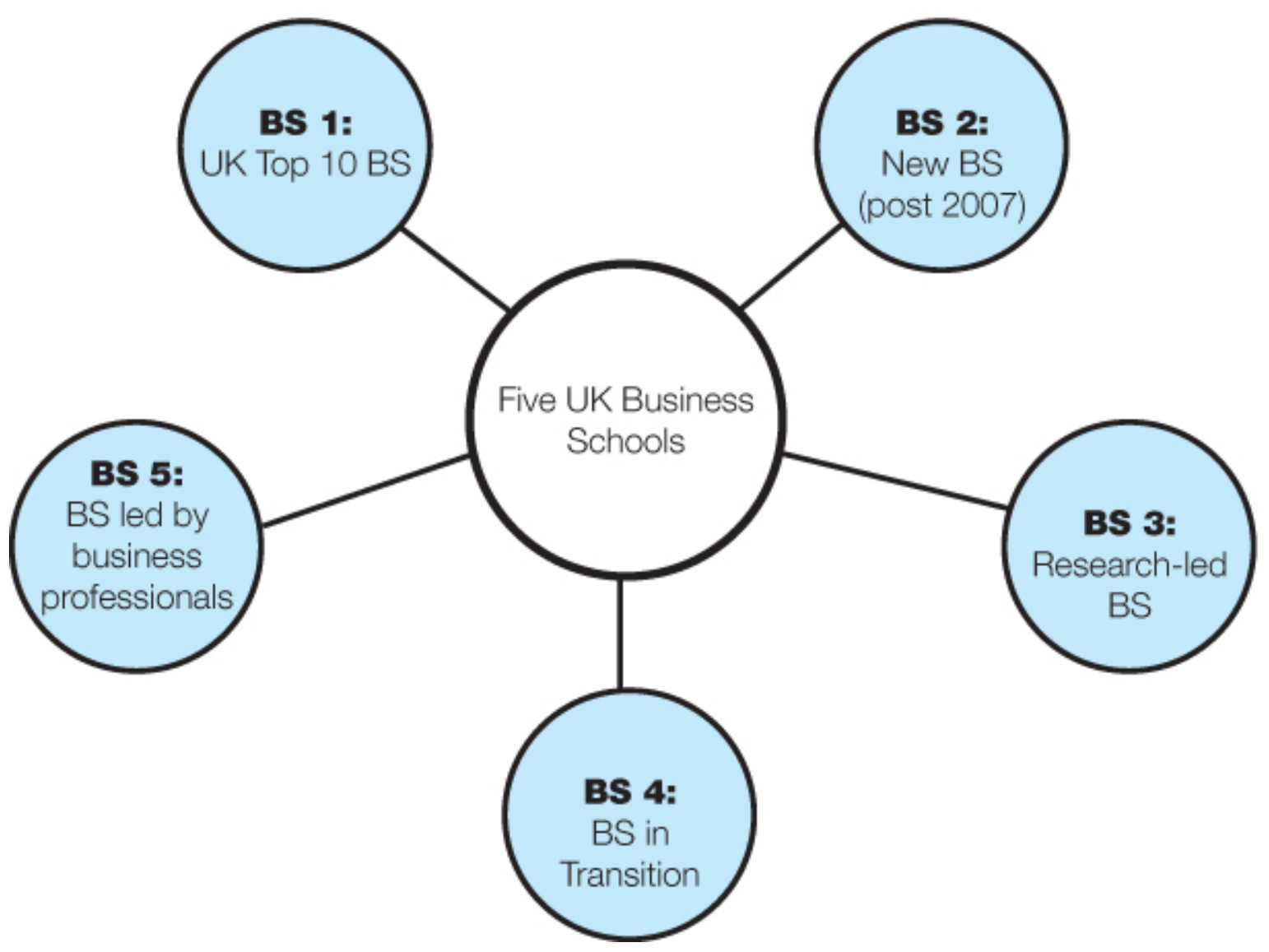

These five business schools form a key element of the case-study investigation together with the following core interview themes/questions as highlighted in Figure 1.3: Interview Discussion Themes. 
Figure 1.3: Interview Discussion Themes

\begin{tabular}{|l|l|}
\hline 1 & $\begin{array}{l}\text { Please spend a few minutes telling me about the main attributes of this } \\
\text { particular school of management/business school }\end{array}$ \\
\hline 2 & $\begin{array}{l}\text { What are the key strategic priorities for the school? } \\
\text { where, what? }\end{array}$ \\
\hline 3 & $\begin{array}{l}\text { Please describe the competitive environment, including the main } \\
\text { challenges for the school? }\end{array}$ \\
\hline 4 & $\begin{array}{l}\text { Has the school implemented a programme of change recently - if so why? } \\
\text { How much marketing does the school undertake? }\end{array}$ \\
\hline 6 & $\begin{array}{l}\text { What is your view on whether business schools including this one, need } \\
\text { to be more business-like? Do you have anything further to add? }\end{array}$ \\
\hline 7
\end{tabular}

Secondary data sources to substantiate the interviews were also collated including: internal documents such as strategy documents (as available), university/business school website data, including; press releases and news articles, as well as relevant journal articles.

\section{FINDINGS}

A useable response rate of 20 completed questionnaires, was realised from the survey of senior managers. The profiles of respondents were: Dean (4), Director of Teaching and learning (4) Head of business school (3), Pro Vice Chancellor and Dean (2) Sub 
Dean Faculty of Business Enterprise and lifelong learning (2) Deputy Director (2) MBA Director (1), Associate Dean (1) and Professor (1).

In order to undertake validity testing of the instrument, as well as eliminating the risk of bias from the questionnaire and providing an opportunity to authenticate the key themes for interview, the draft questionnaire and semi-structured interview questions were tried and tested on two senior managers at two different business schools in the East of England. These senior managers were able to clarify understanding of the questionnaire before it was sent to the selected sample population, whilst also providing advice to enhance the interview question themes.

\section{$\underline{\text { Top three Strategic Issues }}$}

Analysis of the data provided to the questionnaire (Q1) highlights the top three strategic issues as: funding (11), student recruitment (7) and relevance of courses/research to industry and employers (6). Further areas highlighted within the responses, as key strategic issues are included within model (Figure 1.1), which helps to identify the challenges, as well as the opportunities currently facing UK business schools.

Financial viability due to funding conditions is understandably a key issue and although none of the schools within the case-study analysis directly state that 'making money' is a key strategic priority, it is clear that external income, including student fees is an essential component of maintaining stability and to an extent profitability, to increase security. It is established that 'the search for financial resources to cover operational costs and support research efforts is an ongoing challenge for most business school deans' (D'Alessio and Avolio, 2009: 2). It may also be suggested that it is a bigger challenge for UK business schools because historically they have relied upon 
maintaining their funding solely from student tuition and Government funding, while also trying to stake their claim as 'international players', attempting to compete within the global arena, against those business schools with financing models such as those in the USA. As D'Alessio and Avolio (2009) state in addition to the funds generated by the schools themselves, business schools in the USA also have access to donations such as grants, endowments or gifts, from individuals, corporations or foundations. In many countries including the UK, legislation does not exist to promote donations, but rather bureaucracy may be more inclined to restrict their implementation.

A summary of the key strategic priorities for the five case-study business schools is summarised in Figure 1.4: Top three key strategic priorities. 


\section{Top Three Key Strategic Priorities}



However, the case-study analysis highlights that some of the business schools have been more successful than others in terms of maintaining financial stability, due to horizon scanning and forward planning to minimise risk, or even make profit. It may be suggested that some business schools are adapting a more business-like 'Classical' strategic approach (Whittington, 2006) which is demonstrated in the casestudy analysis by the top ranking BS1 which has moved from a position of: "Losing 
$£ 3$ million in 2004 , to making about £5million overall for the last two years." The fact that BS1 has successfully maintained growth in the UK and expanded external income via student recruitment internationally is attributed to the arrival of a new dean (in 2004). While in comparison BS4 admits: "The University has been a little slow to react to changes in the national agenda, funding etc - we are playing catch-up." A situation which they are hoping to rectify by fundamentally adapting their strategic approach and making the transition from the existing school of business and economics to the new college of business, economics and law; a move which is designed to expand opportunities for growth, in terms of student recruitment and research.

It may be argued however, that 'under funding' balanced against pressure from governments and regulatory bodies (QAA and REF (previously RAE)) has always existed, continually presenting the challenge of requiring business schools to balance quality education against a criteria of cost efficiency and organisational effectiveness (Thomas, 2007). Certainly senior manager's confirm via the questionnaire (Q3) that: external income and specifically the search for new lines of business (5) is second only to student recruitment (7) in terms of the biggest challenge for business schools during the last three years, Figure 1.4. In terms of creative thinking to gain competitive advantage business schools in the USA are already some years ahead. Their search for new lines of business, for example, already includes the sale of journals, case studies, books, newsletters and other publications such as the Harvard Business Review in print or e-format, which in some instances can equate to just under a third (29\%) of overall revenue generated (D'Alessio and Avolio, 2009).

Figure 1.4: Biggest Challenges for Business Schools during the Last Three Years 


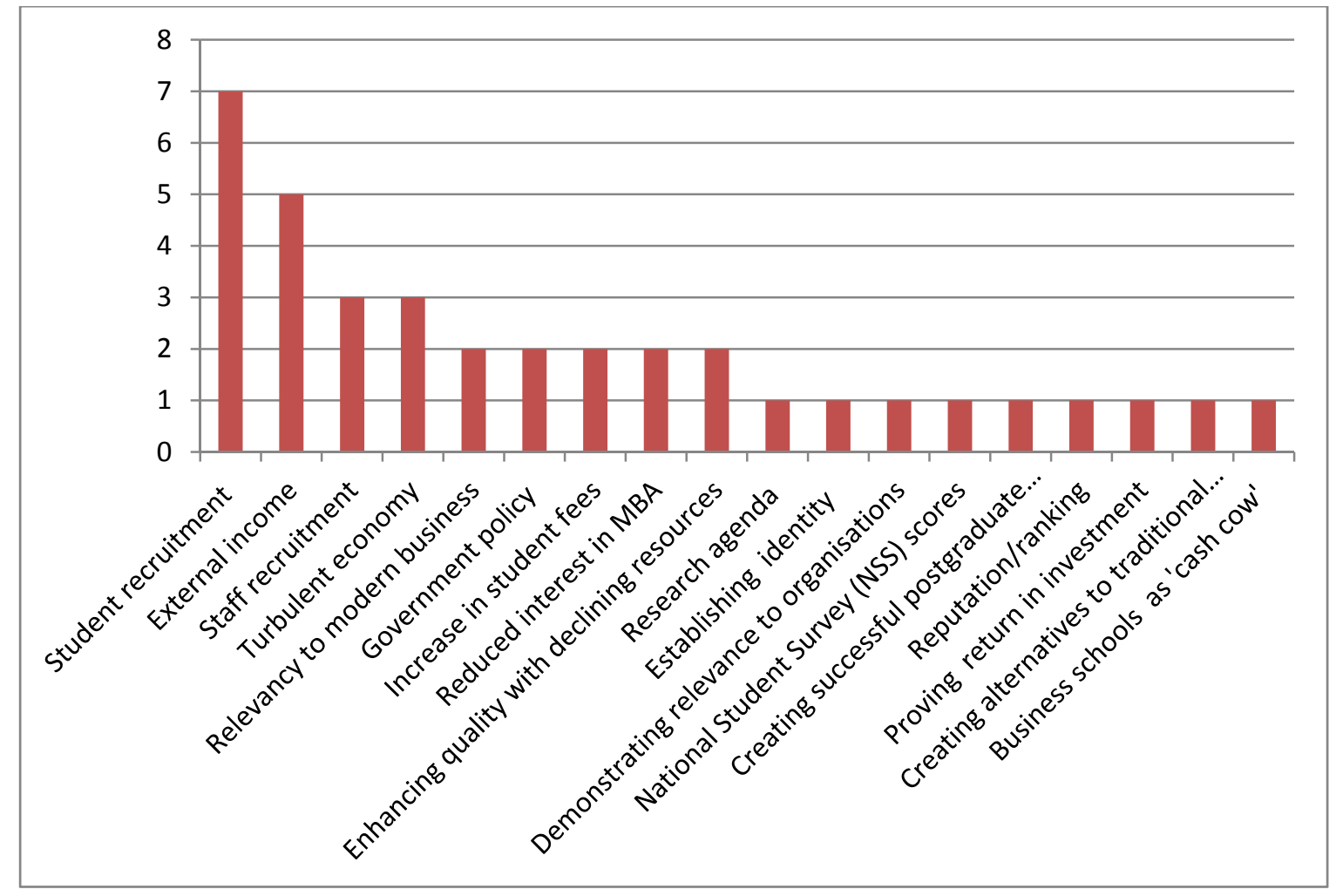

(The number of responders is included down the left axis)

Financial viability; sustainability and survival in the current climate' (7) is also prioritised as the second biggest challenge facing business schools during the next three years (Q4), Figure 1.5.

Figure 1.5: Biggest Challenges Facing Business Schools over the Next Three Years 


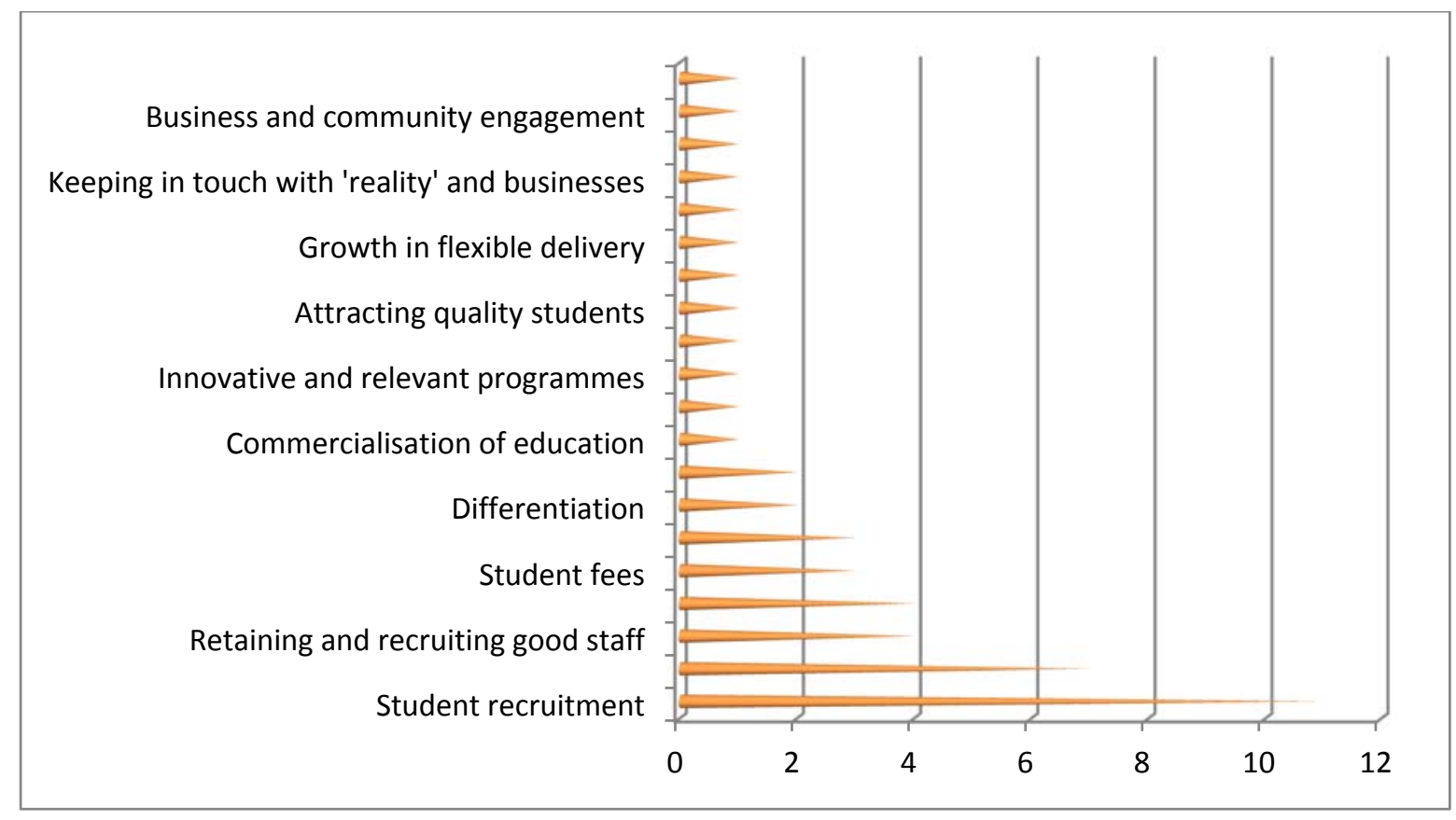

(Number of responders is included on the lower axis).

Interestingly, the case-study analysis draws out rather opposing views to the financial challenges with BS3 stating: "It is all about the money, cutting costs and there is no appreciation of the individual." In fact for BS3 the only challenge of note has been recruiting and retaining quality staff. Interestingly staff recruitment and retention is also ranked by questionnaire responders (Q1) as the fourth most important strategic issue by five respondents, a fact which is supported by Q4, where it is ranked joint third with: 'how to retain research focus and output' (which is arguably also linked to staff) in terms of the biggest challenges for business schools within the next three years, against the backdrop of declining funding. This poses a bit of a dilemma for business schools, that is, how to recruit staff (packages that can realistically be offered) set against a possible continuing reduction in revenue and therefore tight budgets. An issue it may be argued that businesses, specifically the larger corporations have been struggling with for years. It may also be argued as per the strategic issues model (Figure 1.1) that the current concerns about funding will create opportunities for a more 
diverse role for business school staff. It is however also acknowledged that this may be seen as detracting from the core principles of teaching and research, increasing pressure and workloads, which may not suit staff in the longer-term.

Whilst BS4 admits: "Very little has been done to manage the competitive environment, plus internally the university takes $60 \%$ of the school's income," which reiterates the view that some critics (Thomas and Thomas, 2011) still hold that the modern university business school is currently valued much more for its cash-generation abilities and financial strength than its intellectual capabilities and scholarship. However for BS1 issues around funding are related to the National Student Survey (NSS) scores as this business school always achieves a low score due to their large class sizes. In fact the challenge for this particular business school that they are already delivering courses to capacity and now the emphasis needs to be re-focussed on quality with: ..."teaching needing to be brought up to scratch internationally." Although for many business schools, including BS2, the new undergraduate fee regime is a concern: "Undergraduates are our 'bread and butter' in terms of income - it is very much an unknown in terms of the introduction of the higher tuition fees on the long-term picture and how it will affect us this year and beyond." The key challenges influencing strategy in the five case-study business schools (Figure 1.6, below) also reflect those within the model identifying current 'Strategic issues for UK Business Schools' (Figure 1.1). 


\section{Key Challenges Facing the Five Case-Study Business Schools}



It is clear that 'other academic fees and support grants' are second only to Government funding in terms of annual income, so it is envisaged any changes will naturally pose a challenge for many. These figures serve to reiterate the previously highlighted disadvantage for the UK business school sector competing in a global marketplace, against a system such as that employed within the USA, which arguably includes a far more diverse and robust funding model.

\section{Student recruitment}

The emphasis on funding is also directly linked to the focus on student recruitment, because it is an obvious means of increasing external income, a relationship that can 
certainly be aligned with business-like propositions focussing on increasing profit by increasing sales in existing markets (Jobber, 2010). This suggests business schools are just as fallible to challenges posed by the economic climate and current dynamic environment, but also that they recognise this. An awareness reiterated by the fact that 17 out of 20 questionnaire responders (Q2) agree that business schools will need to become more market orientated. As one senior manager questionnaire responder acknowledges: "The business school has always been market orientated but student recruitment will become more difficult with higher undergraduate fees and restrictions on overseas visas - budgets will be squeezed and delivering the appropriate standard of HE will become more problematic." The results from this study show student recruitment as the second highest strategic issue facing today's business schools (Q3). While more than half (11) predict it will remain the biggest challenge facing business schools over the next three years (Q4). As depicted within the 'Strategic issues for UK Business Schools' model (Figure 1.1) the emphasis on student recruitment to maintain income may also be seen as an opportunity to re-establish identity and imbed a more sustainable unique selling point (USP) both at home and internationally.

The case-study analysis also supports a focus on student recruitment in terms of a pertinent strategic priority. There is also a more diverse range of issues identified that are all contributing to strategy formation. In some instances these are challenging the emphasis on increasing the quantity of students at the detriment of; 'enhancing the student experience' (in terms of employability); 'Improving the quality of the student experience' (value-added) and improving delivery to students through new courses, (BS3, BS4 and BS5). In fact BS3 goes as far as to state: "Other schools are jumping over each other to get the students. Teaching should be the focus. The current 
competitive environment is detrimental." Certainly, more than three quarters of senior managers (17) responding to Q6 which focuses on the impact of more business schools in the emerging economies agree this would impact on the number of International students currently attending UK business schools, presumably detrimentally.

In terms of whether the strongest competition for International students will come from, UK or overseas based business school responders (Q7) were less clear narrowly citing that they thought the biggest threat will come from overseas (8) followed closely by the UK (7) and Both (5). It is pertinent therefore that business schools are also increasingly seeing their role as an international one in relation to the competitive landscape and in terms of threats and opportunities for student recruitment. The case study analysis has helped to explain in more detail the reasons for the emphasis on student recruitment as a key strategic challenge for the future in terms of the need to respond to the predicted decline in UK undergraduate student numbers. Figures are expected to decrease by an average of $10 \%$ (Coughlan, 2012) due principally to the introduction by the Government of the higher undergraduate fees (up to $£ 9,000$ ), plus the $A A B$ entry grade regime is expected to impact detrimentally on funding. This has led many UK business schools (BS1, BS2 and BS5) to place more emphasis on recruiting international students as depicted in two issues within the 'Strategic Issues for UK Business Schools' model with the inclusion of 'Internationalisation' which refers to a myriad of issues from financing to recruitment but also a focus on the 'Concentration of clientele from Asia' which is seen by responders as a potential area for market growth. However, the introduction of tighter Border controls proposed in 2011 amid fears that student visas were being abused, threatens this £5bn a year HE income stream (Coughlan, 2012). HEFCE secondary research data highlights that on 
average in $2009 / 10$ overseas income accounts for approximately $10 \%$ of total university revenue. Though for some business schools such as BS1 it is envisaged that this figure is much higher, as outlined from comments about their international market presence in Figure 1.9 (below).

\section{Selected Case-Study Comments: International Market Presence}

BS 1 "We punch above our weight anyway as we have such a cracking team. We're constantly reacting to international demand, so we've opened centres in South America, Greece, Miami, Dubai, Shanghai, India and Eastern Europe - though we've had to shut down Jamaica and Kuala Lumpur due to a lack of demand."

BS 2 "A quarter of our income currently is from international students, three countries currently with agents. The numbers have gone down lately, but in the long-term we plan to continue exporting the on-line education partnership model; we are planning for seven or eight partners."

BS 5 "The number of post-graduate students is expanding; this is an international student recruitment focus area. The numbers of international students have increased - though recent applicants were concerned we were going to triple the fees."

Working closely with international centres or agents is a key component of the majority of international student recruitment strategies as described by the case-study examples, although business schools are still keen to work more closely with relevant UK strategic partners including local businesses and Government.

$\underline{\text { Relevance to Industry and relationships with local businesses }}$

When the senior managers, responding to the questionnaire were asked to highlight in order of priority those strategic partners they envisage working more closely with 
(Q5), responders' jointly highlighted local businesses and Government: local and/or national as the priority groups, as opposed to other business schools, and local community groups. The connection to Government is envisaged as a focus on policy - economic and education, which impacts on universities and business schools. Many business schools also link in with local government via the local chamber of commerce, Local Enterprise Partnerships (LEPs) and through joint initiatives such as a focus on youth employment at a local level, as highlighted via the case study research.

The ability to make closer links with local businesses is attributed by BS5 to the fact that "Most of our staff have business experience, making it easier for us to connect in." There is also evidence from the case-study analysis that strong partnerships with local businesses are a top priority to increase 'employability' opportunities for students. BS2 for example has been formed as a partnership with an entrepreneur based in the area with FE and HE locally in order to promote opportunities for students of all ages to gain the relevant business skills and experience. This also suggests a direct link to maintaining relevance to industry, delivering innovation and enterprise in order to establish a sustainable business model; all related strategic issues for UK business schools (Figure 1.1).

Additionally, the implementation of strategy to encourage student employability skills is already visible through engagement with local businesses in terms of; 'live project work' (BS1 and BS4) and this is reflected in the postgraduate fee structure in BS3; where "...big tuition fees are tailored to the expectation of big salaries for students in their future careers." The importance and relevancy of courses to local businesses is also a priority as outlined by BS4:"The school is very engaged with the region, which is having more effect on what we do - there are very good external links, student 
exchanges and regional business relationships." However BS3 highlights the fine balance between working in partnership with business for mutual gain, which allows business schools to maintain academic rigour, and "Serving the interest of business in the interests of profit-making", highlighting: "Business schools are encouraged to serve corporations, we do that here." While BS5, highlights the CIPD and professional courses as a key area for growth on the basis that: "The curriculum needs to deliver more flexibility to encourage continued employability plus training as an opportunity for students and local businesses."

It may be argued that this presents evidence of strategic planning and gives some credence to the suggestion by critics including Starkey, (2007) that for many business schools the automatic response to changes in the competitive environment has been to concentrate on the bottom line, such as increasing fees or student numbers, hence the consistent emphasis on new courses and post-graduate recruitment in the UK and overseas. Many critics also highlight business school's penchant for working more closely with the business community for profit, as well as to increase relevance (Lorange, 2005, Prince, 2007, Muff, 2012). Though there is evidence from the questionnaire and case-study analysis that closer working relationships with local businesses are equally relevant for the benefit of the students, which may be deemed as a clear reaction to the current levels of graduate unemployment, as the latest data from Osborne (2012) shows $25 \%$ of 21 -year-olds who left university with a degree in 2011 were unemployed, and it is a similar picture in 2012 where this figure has reduced only very slightly to approximately $23 \%$ (Paton, 2012). This does however emphasise the complex multi-faceted responsibilities of business schools to adopt a core set of values to contribute to the development of societies at large, (Porter, 2011, Rayment and Smith, 2013) juxtaposed, some elements of which are also illustrated within the 
model (Figure 1.1) focussing on strategic issues for UK business schools, against the necessity to 'balance the books' (or make profit, BS1). This has been further enhanced since 2012 with the introduction of higher undergraduate student fees which critics argue has created a consumer environment, where value for money is paramount (Baxter, 2012) which places higher education in a difficult position of trying to balance academic integrity and social responsibility with the requirements of students and senior managers, a position already familiar for many businesses, it can be argued.

\section{Formation and monitoring of strategy}

Even with a stronger strategic focus on enhancing partnerships with local businesses for mutual gain (Muff, 2012), and an emphasis on student recruitment due to the evident concerns about financial viability, this primary research demonstrates there are still vastly differing approaches to strategy preparation, monitoring and evaluation in UK business schools. It is acknowledged that business schools rarely have a separate strategy (Q8) from that of the university, which is confirmed by more than half of questionnaire responders (13 out of 20). Therefore, responding to environmental changes or government policy quickly will be more difficult due to the number of decision-makers at senior management level that will need to debate, negotiate and finally agree any changes. Although, it is suggested from the comments that accompany responses to this particular question that the majority of senior managers agree with the business school strategy being interwoven into the university strategy: Comment 1:"We do have limited autonomy, this is good practice and ensures we can respond to particular conditions." Comment 2: "Hard to be separate as we have to mesh with it but we do have our own strategies for business engagement and international recruitment of students." 
The case study evaluation also conclusively defines the importance and fervour of senior managers to ensure business school strategy is aligned with the rest of the university strategy. However, it is clear that the frequency and manner in which the business school strategy is originated and reviewed differs greatly with the majority of responses claiming a review either every month or annually.

These findings certainly fit the continuous scanning approach to strategy in order to remain current and in line with overall direction, more commonly adopted by entrepreneurial businesses (Karami, 2007). This also links directly within the context of reduced funding, student recruitment pressures and an increased focus on engagement with strategic partners, such as local businesses, as depicted within the strategic issues model (Figure 1.1). In some instances rapid and/or continuous programmes of strategic change affecting structure and the drive to increase sources of external income are also a necessary aspect of strategy implementation.

\section{Strategic change management and marketing}

Research has already acknowledged that change is an ever-present feature of organisational life, both at an operational and strategic level - consequently organisational change cannot be separated from organisational strategy or vice versa (Burnes, 2004). It is therefore not surprising, more than three quarters (17) of responders to the questionnaire confirmed their business school has implemented a programme of strategic change during the last three years (Q9), citing a selection of primary reasons including; the need to increase funding and build stronger relationships with local businesses; 'new dean, new ideas in response to new challenges and to become even more employer and student focussed, whether that be at the local, regional or international level. 
This is also supported in that all of the business schools included in the case-study analysis have embarked on significant programmes of strategic change. It is fair to say though that the motives and levels of responsibility for implementing the changes are very different across the case-studies, Figure 1.10 (below).

Figure 1.10: Case Study Analysis: Motives and Responsibility for Strategic Change

\begin{tabular}{|l|l|l|}
\hline & Reason & Responsibility \\
\hline BS 1 & Arrival of new Dean & Dean and senior management team \\
\hline BS 2 & University status being granted & Senior management team \\
\hline BS 3 & Competitive environment & Management Board \\
\hline BS 4 & Underperformance (league tables) & Head of BS \\
\hline BS 5 & To meet strategic priorities & The BS Team \\
\hline
\end{tabular}

Those taking responsibility for change management in the case-study examples are also accountable for change management, reiterating the intrinsic link between the two. Comments in relation to responsibility include; BS4 states: "I am the programme; strategic change started on 1 December because we are underperforming in terms of the league table positions, professional service, finance, admin, everything." In contrast BS 5 highlights in much the same way a business would: "Strategic change has been necessary to meet the strategic priorities. We are now better at doing what the market requires, which has meant managing more as a separate entity which is positive in that it has meant fewer stages in decision-making."

However, barriers to change have also been commonplace (Q10), with approximately three quarters of senior managers confirming they experienced them via the 
questionnaire. Staff resistance and resources are acknowledged as the most common barriers; this reiterates the notion of having to do more, within the context of less funding.

Although business schools have been accused by critics of appearing more proactive in making strategic changes due to the introduction of ranking systems, (this is confirmed in terms of BS4), and focusing primarily on product tinkering, packaging and marketing (Friga et al, 2003). Certainly marketing is highlighted by three quarters of responders (15) as having become more of a priority for the vast majority of business schools,(Q12) which is attributed primarily to the 'dynamic environment' and both are noted as key strategic issues (Figure 1.1).

Although again resources are highlighted as an issue for many (Q11), as less than half, (8 out of 20) business schools have their own marketing team. The case-study analysis also highlighted that marketing is increasing in prominence though the resources in some instances are not there to support this. BS2 for example, attributes a necessary increase in marketing communications to the transition of undergraduate students to "customers" due to higher fees, whilst the fact that this business school does not have its own marketing team is identified as an issue due to the fact that "lecturers with marketing expertise clash with the central team, so it may have been easier if an intermediary was available to liaise with them." While BS3 has one dedicated marketing person it is also acknowledged that a lot of the staff are actively working for marketing specifically to increase the numbers of international students, specifically from China. Whilst, BS5 also acknowledges that despite being able to recently recruit two posts, a marketing and a web officer: "Marketing is increasingly part of the job for all." 


\section{Adopting a business-like approach - financial and reputational success}

In much the same way it may be argued that a business would manage tight resources, reduced funding and the need to secure growth through increasing 'customer' numbers, business schools are finding themselves in a fiercely competitive arena, as depicted within the Strategic Issues for UK Business Schools model (Figure 1.1), where threats and challenges are coming from multiple stakeholders including; Government, other UK and International business schools, as well as private universities and education providers. There is evidence to suggest that these factors are leading to some business schools adopting a more 'business-like' approach (BS2), although others (BS1):"Genuinely don't believe they could be more business-like", while BS3 is: ...."against this because competition in their view is not healthy, although they acknowledge the need to play the game to survive." BS5 are quick to clarify the difference between being more business-like (which is welcomed) and not running (the business school) like a business, driven only by financial targets. Certainly for BS4 being more business-like is a 'desirable, intentional strategic approach', perhaps more a case of 'practicing what they preach': "It's not just business schools that need to be more business-like, to some extent it is easier for us - every university needs to be more business-like and recognise this is the market we're in." In terms of whether there is a correlation between those UK business schools who are adopting a 'business-like' approach and financial and reputational success, to an extent it can be argued that when examining the case-study examples a link is evident, but there are also other factors to be considered, which are examined in Figure 1.11: Adopting a business-like approach and the impact on financial and reputational success, (on the next page). 


\section{Adopting a Business-Like Approach and the Impact on Financial and Reputational Success}

\begin{tabular}{|c|}
\hline $\begin{array}{l}\text { BS } 1 \text { Has achieved financial and reputational success - (most business-like) } \\
\qquad \text { Very profitable (financial) } \\
\text { Top ranking (reputation) } \\
\text { Strategy: Has successfully identified and implemented a global strategy }\end{array}$ \\
\hline $\begin{array}{l}\text { BS } 2 \text { Too early to confirm financial or reputational success - (business-like) } \\
\text { Aspirations to be profitable due to involvement of local entrepreneur (financial) } \\
\text { Ranked within the 'Top } 30 \text { universities in the UK when ranked in order of value-added based on } \\
\text { graduate salary (reputation) } \\
\text { Strategy; Focussed on 'transferable skills' not research expertise to encourage employability }\end{array}$ \\
\hline $\begin{array}{c}\text { BS } 3 \text { Renowned for research excellence rather than financial success (does not wish to be business-like) } \\
\text { Constantly evolving due to competitive environment (financial) } \\
\text { 2008 RAE: BS } 3 \text { has been ranked in the Top } 20 \text { UK business schools with } 95 \% \text { of its research being deemed as } \\
\text { of an international standard (reputation) } \\
\text { Strategy; Remain innovative in relation to research excellence }\end{array}$ \\
\hline $\begin{array}{l}\text { BS } 4 \text { Too early to confirm financial or reputational success (aspires to be more business-like) } \\
\text { New school evolving from the School of business and economics to the School of business, economics and } \\
\qquad \begin{array}{c}\text { law, designed to improve finances and reputation (financial) } \\
\text { Previous underperformance in UK league tables } \\
\text { Strategy; Improve reputation }\end{array}\end{array}$ \\
\hline $\begin{array}{c}\text { BS } 5 \text { Has steadily improved reputation particularly with Industry and professional groups and plans are } \\
\text { underway to achieve global growth (aspires to be more business-like) } \\
\text { Aspirational; new business degrees recently launched and focus on global expansion (financial) } \\
\text { Provides courses in close consultation with industry and professional bodies to ensure that graduates have the } \\
\text { range of skills employers are looking for (reputation) } \\
\text { Strategy; Desire to be more business-like in approach to increase student recruitment opportunities }\end{array}$ \\
\hline
\end{tabular}

Interestingly only BS3 is not at all focussed on being more 'business-like' while BS1 believes they have already achieved this, while BS2, 4 and 5 all confirm aspirations to be more business-like' which it may be argued is a clear link to the need to increase profitability, due to the dynamic environment.

It is possible to conclude in terms of strategic approaches that business schools like businesses would benefit from following current strategy theory (Mintzberg et al 2003, Anthony et al 2008) which proposes that organisations have emerging strategies that are not fixed over a five or three year period as there is a need to continually adapt 
due to market conditions. Though, unless universities and specifically business schools, are able to work outside the usual bureaucratic constraints, which Lock (2010, cited in Tahir, 2010) describes as a managerial 'hyper-bureaucracy' that has taken hold in higher education, serving to prolong decision-making, and specifically strategy planning and implementation, it is unlikely that this can become a reality and hence reflect emerging business-like strategic practice.

\section{CONCLUSIONS}

Evidence of business schools reacting to the current dynamic environment by adapting a more business-like approach, scanning the horizon and identifying new markets and opportunities for growth is presented within this paper.

There is empirical evidence from this primary research that there are a number of key strategic issues (as illustrated within the 'Strategic Issues for UK Business Schools' model, Figure 1.1) as well as opportunities, such as the implementation of international student recruitment strategies, the development and launch of new business school models and the introduction of new courses.

Given the current economic climate and dynamic environment, adopting a strategic approach more in line with private business, with a sharper focus on efficiency and operating profit could be considered inevitable, or perhaps even advisable.

It is however important to note that whilst there is an emphasis on increasing the quantity of students, those business schools involved in the case study analysis did not want this to be at the detriment of; enhancing the student experience, in terms of employability and quality. This only serves to reiterate the conflicting pressures on strategy formation for business schools within a dynamic environment. On the one 
hand there is a practical pressure to remain financially viable and perhaps even grow, while on the other, the requirement to deliver quality, developing new courses, essentially doing more with less, arguably a daily pressure more familiar in business.

These essentially competing strategic issues are made more difficult, as the literature review highlights that business schools are also criticised for being out of touch with the business world, (Pfeffer and Fong, 2002) while it is also suggested they opt for working more closely with the business community for profit and to increase relevancy (Lorange, 2005, Prince, 2007, Muff, 2012). The research questionnaire responses support the latter view, identifying local businesses as the priority group, together with Government/local government, as those that business schools wish to work more closely with, not just for profit or relevancy though, but also to increase legitimacy and employability opportunities for students within the locality.

The case-study analysis reveals the conundrum between poor rankings and the implementation of a substantial programme of strategic change. However other issues such as student recruitment and the introduction of the Government's white paper (Students at the heart of higher education, 2011) have all put business schools and universities under more pressure to provide better quality at a lower cost (Cable and Willets 2011), which also explains the high proportion of those experiencing barriers to change, predominantly in the form of staff resistance and resources.

The authors realise that this research is just one facet of the investigations effecting current strategy in UK business schools. The combination of the changing competitive environment; reduced funding and an evolving 'customer' (student) population, plus the diverse nature of the international marketplace for business education ensures 
strategy in business schools should continually provide a useful medium on which to focus further study. 


\section{REFERENCES}

Almog-Bareket, G (2012) Visionary leadership in business schools: an institutional framework. Journal of Management Development 31 (4) pp:431-440.

Angus, I. (2010). Love the questions: University education and enlightenment.

Winnipeg: Arbeiter Ring Publishing.

Anthony, et al. (2008). Mastering emergent strategies - Taking uncertain ideas forward.

Excerpt from Innovator's Guide to Growth; Putting - Disruptive Innovation to work.

Boston Harvard Business Press.[Online]. Available at:

http://blogs.hbr.org/innovation/flatmm/mastering -emergent-strategies.pdf

Accessed on: 15 October, 2012.

Baker, S. (2010) Self-reliance and survival: a US lesson for the UK. [Online]. Available at: http://www.timeshighereducation.co.uk/story.asp?storyCode=412289\&sectioncode=26 Accessed on: 25 September, 2011

Ball, S (2012) Global Education Inc. New Policy Networks and the Neoliberal Imaginary. London: Routledge

Balmer, J.M.T. (2010). Corporate brand identification and corporate brand management: how top business schools do it. Journal of General Management, 35 (4) 77-102.

Balogun, J. \& Hope Hailey, V. (2008). Exploring Strategic Change. 3rd edn. Harlow: 
Pearson Education.

Baxter, S (2012) Tuition fees make students obsess about 'value for money' from their education.

[Online] Available at: http://www.newstatesman.com/blogs/lifestyle/2012/10/tuition-fees-makestudents-obsess-about-value-money-their-education Accessed on: 28 October, 2012.

Bierach, B. (2010). Marketing: Selling business school has never been tougher. [Online] Available at:

http://www.mba-channel.com/channel/article/marketing-business-schools-toughtimes/ Accessed on: 12 August, 2012.

Bevelander, D.L (2012) Who is engaging with whom? Internationalizing opportunities for business schools in emerging economies. International Journal of Educational Management 26 (7) pp: 646-663.

Bok, D. C. (2003). Universities in the Marketplace, The Commercialisation of Higher Education. New Jersey: Princeton University Press.

Burnes, B. (2004). Managing change: A strategic approach to organisational dynamics. 4th ed. Harlow: Pearson Education Ltd.

PMid:15054198

Cabrera, A, \& Bowen, D. (2005). Professionalising global management for the twenty-first century. Journal of Management Development, 24 (9), 791-806. 
Cornuel, E. (2005). The role of business schools in society. Journal of Management Development, 24 (9), 819-829.

Cornuel, E. (2007). Challenges facing business schools in the future. Journal of Management Development, 26 (1), 87 - 92.

Coughlan, S. (2012). UK Applications down as fees rise. [Online].

Available at: http://www.bbc.co.uk/news/education-16787948

Accessed on: 2 March, 2012

Dart, R (2004) Being "Business-Like" in a Nonprofit Organisation: A Grounded and Inductive Typology. Nonprofit and Voluntary Sector Quarterly 33 (2) pp: 290 - 310.

D'Alessio, F. A., \& Avolio, B. (2009). Business schools and resources constraints: A task for deans or magicians? [Online]. Available at: http://www.aabri.com/manuscripts/11912.pdf Accessed on: 1 October, 2012.

Fontanella-Khan, J. (2011). Business education - Meet the deans; Ajit Rangnekar of the Indian school of business. Financial Times [Online]. Available at:

http://www.ft.com/cms/s/2/718678aa-27ae-11e0-a327-00144feab49a.html Accessed on: 12 April, 2013

Friga, P. N. et al (2003). Changes in graduate management education and new business school strategies for the 21st century. Academy of Management Learning 
and Education, 2 (3), 233 - 249.

Hall, R et al (2013) The future of management education in Australia: challenges and Innovations. Education and Training 55 (4/5) pp: 2-8.

Harrington, D and Kearney, A. (2011). The business school in transition: New opportunities in management development, knowledge transfer and knowledge creation. Journal of European Industrial Training, 35 (2), 116-134.

Hawawini, G. (2005). The Future of Business Schools. Journal of Management Development, 24 (9), 770-782.

Hay, M. (2008). Business schools: a new sense of purpose. Journal of Management Development, 27 (4), 371- 378.

Higher Education Funding Council HEFCE, (2011). Financial health of the higher education sector: 2009-10 financial results and 2010-11 forecasts [Online]. Available at: http://www.hefce.ac.uk/media/hefceimported/pubs/hefce/2011/1106/11 06.pdf Accessed on: 12 December, 2012.

Ivory et al. (2005) The future of business schools in the UK. [Online]. Available at: http://wi1.uni-erlangen.de/files/busschool.pdf Accessed on: 15 August, 2013. 
Ivy, J. (2008). A new higher education marketing mix: the 7Ps for MBA marketing. International Journal of Educational Management, 22 (4), 288-299.

Jobber, D. (2010). Principles and practice of marketing. 6th ed. Maidenhead: McGraw-Hill Higher Education.

Karami, A (2007) Strategy formulation in entrepreneurial firms. Aldershot: Ashgate Publishing Ltd.

Khalifa, Salem, A. (2009). Student-as-aspirant; strategic implications for business education. European Business Review, 21 (2),172-190.

Kirp, D. (2003). Shakespeare, Einstein and the bottom line: The marketing of higher education. Cambridge, MA: Harvard University Press.

Lavelle, L (2013) Stanford increases MBA tuition. Business Week [Online]. Available at: http://www.businessweek.com/articles/2013-02-13/stanford-increases-mba-tuition Accessed on: 28 July, 2013.

Leonard-Barton, D. (1992). Core capabilities and core rigidities: a paradox in managing new product development, Strategic Management Journal, Vol.13, 111-25

Lindblom, C. E. (1959). The science of 'muddling through.' Public Administration Review, 19 (2), 79-88.

Lorange, P (2013) Business school culture: customer-focused, virtual and cooperative. 
Education + Training 55 (4/5) pp: 336-347.

Lorange, P (2012) The business school of the future: the network-based business model. Journal of Management Development 31 (4) pp: 424-430.

Lorange, P. (2005). Strategy means choice: also for today's business school! Journal of Management Development, 24 (9), 783 - 790.

Martin, R (2013) Don't let strategy become planning. Available at:

http://blogs.hbr.org/cs/2013/02/dont let strategy become plann.html Accessed on: 28 July, 2013.

Martinez, Z. L.et al (2000). Research expectations at business schools: Responding to changing business education pressures. Journal of Marketing Management, $16(1), 761-778$.

Mintzberg et al. (2003). The strategy process: Concepts, contexts, cases. 4th ed. Harlow: Pearson Education Ltd.

PMid:14619151

Moogan, Y. J. (2011). Can a higher education institution's marketing strategy improve the student-institution match?. International Journal of Educational Management, 25 (6), $570-589$. 
Muff, K (2013) Developing globally responsible leaders in business schools. Journal of Management Development 32 (5) pp: 487-507.

Muff, K (2012) Are business schools doing their job? Journal of Management Development 31 (7) pp: 648-662.

Onzono, Iniguez de, S., \& Carmona, S. (2007). The changing business model of B-schools. Journal of Management Development, 26 (1), 22-32.

Osborne, H. (2012). Graduate unemployment levels on a par with school leavers. [Online] Available at: http://www.guardian.co.uk/money/2012/feb/22/graduates-unemployment-levelsschool-leavers Accessed on: 1 March, 2012.

Paton, G (2012) Up to a fifth of graduates 'without work' after university. Telegraph [Online] Available at: http://www.telegraph.co.uk/education/educationnews/9379225/ Up-to-a-fifth-of-graduates-without-work-after-university.html Accessed on 13 March, 2013.

Pfeffer, J., \& Fong, C. T. (2002). The end of business schools? Less success than meets the eye. Academy of Management Learning and Education, 1 (1), 78-95.

Pfeffer, J., \& Fong C. T (2004). The business school 'Business': Some lessons from the U.S experience. Journal of Management Studies, 41 (8), 1,501 - 1,520.

Porter, M. (2011). Creating shared value: How to reinvent capitalism and unleash a wave of innovation and growth. Harvard Business Review, 89 (1/2), 62-77. 
Prince, C (2007) Strategies for developing third stream activity in new university business schools. Journal of European Industrial Training, 31 (9), 742 - 757.

Rayment, J and Smith, J (2013) The current and future role of business schools. Education + Training 55 (4/5) pp: 478-494.

Schlegelmilch, B. B., \& Thomas, H. (2011).The MBA in 2020: will there still be one? Journal of Management Development, 30 (5), 474 - 482.

Shahaida, P. et al. (2009). A conceptual model of brand-building for B-schools: an Indian perspective. International Journal of Commerce and Management, $19(1), 58-71$.

Siebert, S and Martin, G (2013) Reputational challenges for business schools: a contextual perspective. Education + Training 55 (4/5) pp: 429-444.

Starkey, K. et al. (2004). Rethinking the business school. Journal of Management Studies, $41(8), 1,521-1,531$.

Starkey, K., \& Tempest, S. (2008). A clear sense of purpose? The evolving role of the business school. Journal of Management Development, 27 (4), 379 - 390.

Starkey, K., \& Tiratsoo, N. (2007). The business school and the bottom line. Cambridge: University Press. 
Syvertsen, C. (2008). What is the future of business schools? European Business Review, 20 (2), 142-151.

Thomas, H., and Cornuel, E (2012) Business schools in transition? Issues of impact, legitimacy, capabilities and re-invention. Journal of Management Development 31 (4) pp: 329-335.

Thomas, H., and Cornuel, E. (2011). Business school futures: evaluation and perspectives. Journal of Management Development, 30 (5), 444-450

Thomas, H., and Thomas, L. (2011). Perspectives on leadership in business schools. Journal of Management Development, 30 (5), 526-540.

Thomas, H. (2007). An analysis of the environment and competitive dynamics of management education. Journal of Management Development, 26 (1), 9 - 21.

Whittington, R. (2006). What is Strategy - and does it matter? Thomson Learning: London.

Willetts, D., \& Cable, V. (2011). Department for business, innovation and skills: Higher Education-Students at the heart of the system. Available at: http://c561635.r35.cf2.rackcdn.com/11-944-WP-students-at-heart.pdf Accessed on: 12 February, 2012

Wilson, D. C and Thomas, H (2012) The legitimacy of the business of business schools: 
what's the future? Journal of Management Development 31 (4) pp: 368-376.

Wilson, D. A. (2007). Tomorrow, tomorrow and tomorrow: the "silent" pillar.

Journal of Management Development, 26 (1), 84 - 86. 